\title{
DAMPAK PENGANGGURAN \\ KEMISKINAN DAN KONSEP TEORITISNYA PADA PANDEMI COVID-19
}

\author{
I Ketut Kasna \\ Fakultas Ilmu Sosial dan Ilmu Politik Universitas Mahendaradatta Denpasar \\ johnkresna44@gmail.com
}

\begin{abstract}
Abstrak - Pengangguran dan kemiskinan merupakan salah satu tema sentral dalam kehidupan bermasyarakat dan bernegara. Di Indonesia pengangguran dan kemiskinan memang belum pernah menjadi tema utama dalam pemilu, tetapi telah cukup banyak seminar, diskusi publik, lokakarya dan launching program pemerintah. Menurut Biro Pusat Statistik, jumlah pengangguran dan kemiskinan seluruhnya pada tahun 2019 mencapai 38.000 .686 orang (37,70\% dari total angkatan kerja).

Menghadapi pengangguran kemiskinan diakibatkan dampak pandemi covid-19, pemerintah saat ini setidaknya mempunyai empat program yaitu Padat Karya Produktif, memperluas perkebunan melalui pelatihan terpadu, Usaha mandiri, dan TKPMP (Tenaga Kerja Pemuda Mandiri Profesional). Program-program ini mempunyai orientasi dan kelompok sasaran yang berbeda-beda, yang mencerminkan kompleksitas masalah pengangguran dan kemiskinan. Namun sepertinya program-program tersebut belum diimplementasikan secara komprehensif, sehingga masing-masing program terkesan bersifat parsial, tidak terkait satu sama lain apalagi dengan program-program departemen lain, masalah kemiskinan, kelompok rentan, dan semakin meningkatnya pengangguran perlu mendapat perhatianutama.

Permasalahan tersebut juga membawa pengaruh negatif, seperti semakin longgarnya ikatan sosial dan melemahnya nilai-nilai, serta hubungan antar manusia. Selain untuk menghadapi berbagai dampak negatif perubahan sosial yang diabaikan konsep teorinya, gejala yang dialami kini adalah perubahan sosial budaya yang sangat mendasar. Akselerasi informasi gelombang teknologi membawa perubahan cukup signifikan pada penanggulangan kemiskinan yang merupakan dampak pandemi covid-19, baik pada tataran surface structure (sikap dan pola-pola perilaku) dan deep structure (sistem nilai, pandangan hidup, filsafat dan keyakinan).

Perubahan terjadi karena kontak budaya antar yang dimaknai adanya dialektika nilai-nilai baru dengan nilai-nilai lama yang saling mendominasi, yang memungkinkan terjadinya homoginesis dan meoliberalisasi pada seluruh aspek kehidupan. Kondisi ini menimbulkan spit dan kegamangan nilai, dalam pencegahan penanggulangan pandemi covid-19 lebih menggunakan nilai modern dengan memarginalkan nilai transcendental. Akibatnya terjadi dampak yang berkepanjangan berbagai bentuk penyimpangan nilai moral yang tercermin dalam corak, gaya dan pola hidup masyarakat dari kemiskinan akibat dampak pandemi covid-19.
\end{abstract}

Kata Kunci: kemiskinan pengangguran dan teorinya, Dampak pandemi covid-19.

Abstract - Unemployment and poverty are one of the central themes in community and state life. In Indonesia unemployment and poverty have never been the main themes in elections, but there have been quite a number of seminars, public discussions, workshops and launching government programs. According to the Central Bureau of Statistics, total unemployment and poverty in 2019 reached $38,000,686$ people (37.70\% of the total workforce).

Facing poverty unemployment caused by impact pandemic covid-19, governmentcurrently has at least four programs namely Productive Labor Intensive, expanding plantations through integrated training, independent business, and TKPMP (Independent Professional Youth Workers). These programs have different orientation and target groups, which reflect the complexity of the problem of unemployment and poverty. However, it seems that these programs have not been implemented comprehensively, so that each program seems to be partial, not related to each other especially with other departmental programs, the problem of poverty, vulnerable groups, and increasing unemployment need to get major attention.

These problems also bring negative influences, such as increasingly loosened upsocial ties and 
weakening of values, and relationships between people. In addition to dealing with various negative impacts of social change that are ignored by the concept of the theory, the phenomenon experienced now is a very basic social cultural change. Information wave accelerationtechnology bring significant changes to poverty reduction which is an impact pandemic covid-19, both at the level of surface structure (attitudes and patterns behavior) and deep structure (value systems, outlook onlife, philosophy and beliefs).

Changes occur because of cultural contact between the meaning of the dialectics of new values with old values that dominate each other, which allows homoginesis and meoliberalisation in all aspects of life. This condition causes spit and uncertainty in the value of preventionpandemic covid-19 uses more modern values by marginalizing values transcendental. As a result there is a prolonged impact of various forms of moral value distortionreflected in the style, style and lifestyle of people from poverty due to impact pandemic covid-19.

Keywords : unemployment poverty and its theory, Impact pandemic covid-19.

\section{BAB I PENDAHULUAN}

Kemiskinan merupakan fenomena yang sudah ada sejak zaman pra reformasi, sampai masa reformasi saat ini. Ini merupakan masalah yang signifikan yang sedang dihadapi oleh pemerintah kita pada saat ini. Begitu banyak upaya pemerintah dalam membuat berbagai kebijakan demi mengatasi permasalahan kemiskinan tersebut, akan tetapi, kemiskinan masih saja belum bisa diatasi sepenuhnya oleh pemerintah. Jika kemiskinan, sebenarnya kebijakan tersebut dapat menangani kemiskinan yang ada di negara kita sekarang. Jadi siapakah yang salah dalam hal ini? Pemerintah kah? Pejabatkah? Atau masyarakat? Hal ini memang menjadi pertanyaan besar bagi kita semua terutama pada pengamat-pengamat ekonomi di Indonesia.

Jadi atas dasar statemen-statemen di atas itulah penulis berusaha mengkaji berbagai persoalan yang mengenai penanganan kemiskinan di negara Indonesia Salah satu penghambat pembangunan ekonomi adalah pengangguran dan kemiskinan. Ia merupakan tolak ukur bagi sebuah negara apakah pembangunan yang tengah berlangsung dapat dinikmati oleh segenap warga negaranya tanpa memandang halhal yang bersifat atributif. Dengan kata lain, pembangunan yang berlangsung benar-benar merata dalam masyarakat. Kita menelaah kebijakan-kebijakan yang telah ditetapkan oleh pemerintah dalam upaya mengentaskan masyarakat dari Pengangguran dan kemiskinan dalam masa pandemi covid-19 ini.

Kemiskinan bukan merupakan sesuatu yang berdiri sendiri, sebab ia merupa- kan akibat dari tidak tercapainya pembangunan yang berlangsung. Dalam hal ini, pengangguran kemiskinan akan semakin bertambah seiring tidak terjadinya pemerataan pembangunan di perdesaan.

\section{BAB II PEMBAHASAN}

\section{Program yang dilaksanakan pe- merintah dalam menanggulangi pengangguran dan kemiskinan.}

Beberapa program yang tengah digalakkan oleh pemerintah dalam menanggulangi pengangguran kemiskinan antara lain dengan memfokuskan arah pembangunan pada tahun 2019 pada pengentasan pengangguran kemiskinan. Fokus program tersebut meliputi 5 antara lain:

a) Menjaga stabilitas harga bahan kebutuhan pokok

b) Mendorong pertumbuhan yang berpihak pada rakyat miskin

c) Menyempurnakan dan memperluas cakupan program pembangunan berbasis masyarakat

d) Meningkatkan akses masyarakat miskin kepada pelayanan dasar

e) Membangun dan menyempurnakan sistem perlindungan sosial bagi masyarakat miskin.

Dari 5 fokus program pemerintah tersebut, diharapkan jumlah rakyat miskin yang ada dapat tertanggulangi sedikit demi sedikit. Beberapa langkah teknis yang digalakkan pemerintah terkait 5 program tersebut antara lain: menjaga stabilitas harga bahan kebutuhan pokok. Fokus program ini bertujuan menjamin daya beli masyarakat miskin/keluarga miskin untuk memenuhi kebutuhan pokok terutama be- 
ras dan kebutuhan pokok utama selain beras.

Program yang berkaitan dengan fokus ini seperti:

- Penyediaan cadangan beras pemerintah 1 juta ton

- Stabilitasasi/kepastian harga komoditas primer

- Mendorong pertumbuhan yang berpihak pada rakyat miskin.

Fokus program ini bertujuan mendorong terciptanya dan terfasilitasinya kesempatan berusaha yang lebih luas dan berkualitas bagi masyarakat/keluarga miskin.

2. Kondisi ekonomi indonesia saat dihadapkan banyaknya pengangguran dan kemiskinan akibat pandemi covid-19.

Bangsa Indonesia perlu mewaspadai kondisi kemiskinan dan pengangguran yang terjadi saat ini. Walaupun secara statistik tahun 2019 terjadi penurunan kemiskinan menjadi 28,59 juta orang atau 11,6 persen, secara kualitas kemiskinan justru mengalami involusi dan cenderung semakin kronis. Parameter yang lazim digunakan para analisis dalam menetapkan jumlah kemiskinan adalah lebih cenderung pada pendekatan pemenuhan kebutuhan pokok. Dari hal ini, seseorang dikatakan miskin manakala dalam pemenuhan kebutuhan pokoknya yakni makanan, asupan kalorinya minimal $2.100 \mathrm{kkal} / \mathrm{hari}$ perkapita. Selain dengan pendekatan asupan kalori, kemiskinan juga diukur dengan menambahkan parameter pemenuhan kebutuhan pokok/dasar non makanan yang meliputi pendidikan, sandang dan hal-hal yang dikemukakan di atas. Beranjak dari pendekatan berbasis hak yang menyatakan bahwa masyarakat miskin mempunyai hak-hak dasar yang sama dengan anggota masyarakat lainnya. Kemiskinan tidak lagi dipahami hanya sebatas ketidakmampuan ekonomi, tetapi juga kegagalan memenuhi hak-hak dasar dan perbedaan perlakuan bagi seseorang atau kelompok orang dalam menjalani kehidupan secara bermartabat.

Secara umum kemiskinan dan pengangguran lazim didefinisikan sebagai kondisi dimana seseorang tidak dapat memenuhi kebutuhan dasar nya dalam rangka menuju kehidupan yang lebih bermartabat dan pengangguran dihadapkan pada orang-orang yang hidup bebas, malas bekerja, kemiskinan dan pengangguran merupakan masalah kompleks yang dipengaruhi oleh berbagai faktor yang saling berkaitan antara lain tingkat pendapatan, kesehatan, pendidikan, akses terhadap barang dan jasa. Lokasi geografis, gender dan kondisi lingkungan.

\section{Penyebab kemiskinan dan pen- gangguran di indonesia sampaisaat ini masih belum bisa teratasi sepe- nuhnya. \\ Maka jelaslah, kenapa hingga kini} masalah kemiskinan dan pengangguran belum juga dapat ditekan hingga pada titik yang terendah, karena masalah kemiskinan dan pengangguran ternyata merupakan masalah yang kompleks dan banyak dipengaruhi oleh faktor-faktor dalam setiap sisi kehidupan. Meskipun berbagai upaya telah dilakukan oleh pemerintah untuk mengentaskan kemiskinan, tapi hingga kini faktanya masih banyak rakyat Indonesia yang masih hidup di bawah garis kemiskinan.

Sepertinya pemerintah harus lebih jeli lagi dalam memahami masalah kemiskinan dan pengangguran. Karena selama ini, banyak kebijakan yang ditetapkan pemerintah justru malah memerangi kemiskinan pengangguran, tapi malah menjadikan rakyat semakin miskin. Seperti kebijakan pemerintah untuk menetapkan berbagai pajak kepada rakyat yang kini dirasa semakin membebani rakyat. Karena kita ketahui, banyak hasil pajak yang dipungut dari rakyat tapi penggunaannya melenceng dari yang diharapkan.

Pajak bukan lagi berperan untuk meningkatkan kesejahteraan rakyat. Tapi banyaknya pungutan pajak, malah sering digunakan sebagai ajang korupsi bagi para pejabat kita di pemerintahan. Kekeliruan lain dari kebijakan pemerintah adalah dengan menyerahkan pengelolaan sumber daya alam Indonesia kepada pihak swasta dengan alasan demi efisiensi, kelancaran dan persaingan yang kompetitif dalam mekanisme pasar.

Jika setiap kebijakan yang telah ditetapkan pemerintah tidak juga memikirkan dampak buruknya terhadap tingkat kesejahteraan rakyat dan hanya mementingkan kepentingan para pengusaha 
dengan tujuan mencari laba (keuntungan pihak-pihak tertentu saja), rasanya kemiskinan pengangguran akan sulit untuk dituntaskan.

\section{BAB III PENUTUP}

Pengangguran dan kemiskinan merupakan outcomes (hasil-lanjutan), dari sistem pendidikan. Dan outcomes yang berupa pengangguran kemiskinan ini mengakibatkan timbulnya sejumlah dampak negatif seperti pengangguran, rendahnya kesehatan, tingginya kriminalitas dan sebagainya. Sementara itu proses pendidikan sangat ditentukan oleh kebijakan strategis dan operasional pendidikan, baik pada level kabupaten, provinsi, negara maupun, dalam era otonomi ini.

Penanggulangan kemiskinan pengangguran di Indonesia merupakan masalah komplek dan multidimensional, mengingat komposisi penduduknya yang beragam status sosial dan ekonomi serta geografis yang tersebar. Penanggulangan kemiskinan pengangguran di Indonesia berfokus pada perbaikan kualitas sumberdaya manusia melalui perbaikan kualitas pendidikan dan pelayanan kesehatan. Indonesia telah menyediakan anggaran dana 20 persen dari anggaran pendidikan disamping menyediakan layanan dasar kesehatan untuk orang miskin secara cuma-cu- ma melalui jaminan kesehatan masyarakat (JAMKESMAS). Saat ini pemerintah juga menyiapkan perubahan layanan sistem jaminan kesehatan berbasis asuransi yang mencakup seluruh penduduk sesuai amanat UU Sistem jaminan sosial $\mathrm{Na}-$ sional, selain itu juga masih banyak program-program lain yang akan dilakukan pemerintah dalam menangani

\section{DAFTAR PUSTAKA}

Harian kompas, 23 maret 2008 dalam porsi kredit UMKM membesar bank BUMN Berlomba pacu kredit usaha rakyat.

Stragi kedepan, dalam http://www.google. com $/ 25 / 06 / 2008$

Dr.Samodra Wibawa, Reformasi Administrasi,Bunga rampai pemikiran Administrasi negara/publik, ,pengangguran dan sistiem pendidikan-263. Yogyakarta.gava media.

http://www,presiden.com

http://www.berita kompas.comhttp://ww$\mathrm{w}, \mathrm{tkpkri} /$ penanggulangan kemiskinan melalui UMKM/23-062008.

Departemen Keuangan RI. Data pokok APBN-P2007 DAN APBN-P2008. 